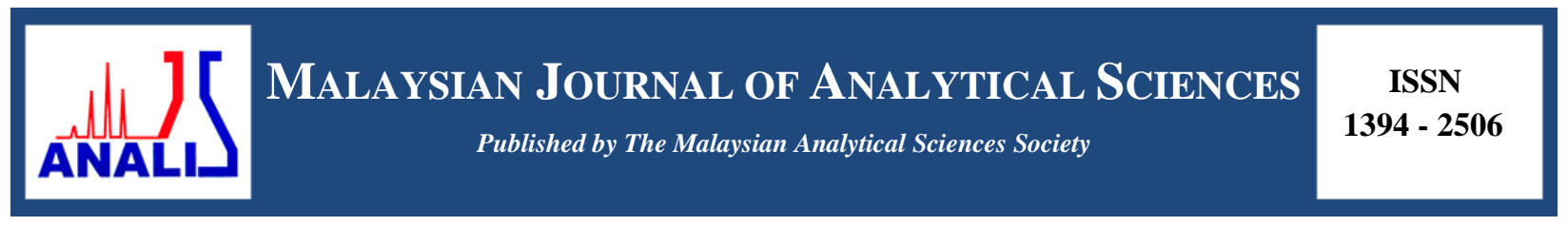

\title{
EFFECTS OF IRGAROL-1051 ON FATTY ACID PROFILE OF SOLITARY CORALS, Fungia fungites AFTER ACUTE EXPOSURE
}

\author{
(Kesan Irgarol-1051 terhadap Profil Asid Lemak Karang Solitari, Fungia fungites \\ selepas Pendedahan Akut) \\ Zainudin Bachok ${ }^{1,2 *}$, Marinah Mohd Ariffin ${ }^{1}$, Mohammed Ali Sheikh ${ }^{3}$, Noor Azhar Mohamed Shazili ${ }^{2}$, \\ Hassan Rashid $\mathrm{Ali}^{3}$ \\ ${ }^{I}$ School of Marine and Environmental Sciences \\ ${ }^{2}$ Institute of Oceanography and Environment \\ Universiti Malaysia Terengganu, 21030 Kuala Terengganu, Terengganu, Malaysia \\ ${ }^{3}$ Tropical Research Centre for Oceanography, Environment and Natural Resources, \\ The State University of Zanzibar, P. O. Box 146, Zanzibar-Tanzania \\ *Corresponding author: zainudinb@umt.edu.my
}

Received: 14 March 2016; Accepted: 23 May 2016

\begin{abstract}
The short term exposure (4 days) was done to Fungia fungites using different concentration of Irgarol to establish the health effects of this species by measuring their fatty acid composition. It was done by comparing fatty acid composition of the fresh, control and exposed groups. The results indicated that, fresh and control samples of $F$. fungites were not significant different $(p>$ 0.05 ) and dominated by Saturated Fatty Acids (SAFA) followed by Polyunsaturated Fatty Acids (PUFA) and the Monounsaturated Fatty Acids (MUFA). However, trends of other tested groups (20, 100 and $500 \mu \mathrm{g} / \mathrm{L})$ were significant different

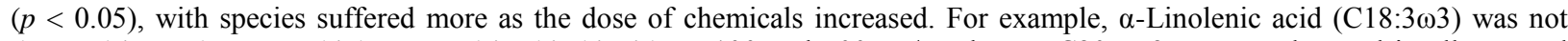
detected in $F$. fungites which exposed in this biocide at 100 and $500 \mu \mathrm{g} / \mathrm{L}$ whereas $\mathrm{C} 20: 5 \omega 3$ was not detected in all exposed groups. These ecotoxicological data proved that Irgarol may affect the fatty acids composition of coral reef organisms even if exposed at the low levels of this biocide.
\end{abstract}

Keywords: Irgarol, booster biocides, fatty acids composition, Fungia fungites, coral reef organisms

\begin{abstract}
Abstrak
Pendedahan jangka pendek (4 hari) telah dilakukan ke atas Fungia fungites menggunakan kepekatan Irgarol yang berbeza untuk membangunkan kesan kesihatan spesies tersebut dengan mengambilkira komposisi asid lemak mereka. Ianya telah dilakukan dengan membandingkan komposisi asid lemak bagi kumpulan segar, kawalan dan yang telah didedahkan. Keputusan menunjukkan bahawa, sampel segar dan kawalan $F$. fungites tidak berbeza secara bererti $(p>0.05)$ dan didominasi olah Asid Lemak Tepu (SAFA) diikuti oleh Asid Lemak Tidak Tepu Poli (PUFA) dan Asid Lemak Tidak Tepu Mono (MUFA). Walaubagaimanapun, corak bagi kumpulan lain yang diuji (20, 100 and $500 \mu \mathrm{g} / \mathrm{L})$ adalah berbeza secara bererti $(p<0.05)$, dengan spesies mengalami sengsara yang lebih apabila dos bahan kima ditingkatkan. Misalnya asid lemak $\alpha$-Linolenat (C18:3 (13) tidak dikesan dalam $F$. fungites yang terdedah dengan biosid peransang ini pada 100 and $500 \mu \mathrm{g} / \mathrm{L}$ manakala C20:5 33 tidak dikesan dalam semua kumpulan yang terdedah. Data ekotoksikologi ini membuktikan bahawa Irgarol berkemungkinan menjejaskan komposisi asid lemak organisma terumbu karang sungguhpun jika terdedah pada tahap yang rendah oleh biosid ini.
\end{abstract}

Kata kunci: Irgarol, biosid perangsang, komposisi asid lemak, Fungia fungites, organisma terumbu karang 


\section{Zainudin et al: EFFECTS OF IRGAROL-1051 ON FATTY ACID PROFILE OF SOLITARY CORALS, Fungia fungites AFTER ACUTE EXPOSURE}

\section{Introduction}

Irgarol-1051 is one among the commonly used alternative antifouling chemical after the prohibition of tri-butyltin (TBT) by International Maritime Organization (IMO) [1, 2]. It was reported that, Irgarol-1051 is very effective in prevention of attachments of biofoulings in recreational boats and yachts [3, 4]. In addition, the Irgarol is considered as a photosystem II inhibitor, which prevents photosynthesis and block conversion of excitation energy into chemical energy [5]. It has been broadly detected in aquatic ecosystems [6-10]. The significant concentrations of Irgarol have been also reported in coastal sediments [11-13]. Numbers of studies have demonstrated the impacts of Irgarol on marine organisms such as corals. For example, Owen et al. [7] reported that $60 \mathrm{ng} / \mathrm{L}$ of Irgarol reduced ${ }^{14} \mathrm{C}$ incorporation in the Madracis mirabilis, while $63 \mathrm{ng} / \mathrm{L}$ reduced net photosynthesis of intact corals. Moreover, $50 \mathrm{ng} / \mathrm{L}$ reduced photosynthetic efficiency (F0/Fm0) of Seriatopora hystrix [5]. It is also revealed that $1000 \mathrm{ng} / \mathrm{L}$ of Irgarol significantly reduced the photosynthesis rate of G. fascicularis and $100 \mathrm{ng} / \mathrm{L}$ reduced the settlement of coral larvae $[4,10]$. The concerns on toxicity nature of Irgarol-1051 to marine habitats lead some countries such as Denmark, UK and Sweden to restrict the use of Irgarol as an antifouling paint to the boats under $25 \mathrm{~m}$ [14]. Studies on detection and distribution have reported the level of Irgarol 1015 in the coastal waters of Asian countries, for example, Singapore [15] and Malaysia [2], however, very little is known about its impact to corals in this region. To our knowledge only the study by Ali et al. [16] has reported the effects of Irgarol to the fatty acid composition of Asian Sea-bass (Lates calcarifer) from Malaysia. This study therefore presents the ecotoxicological data on the impact of Irgarol-1051 in the $F$. fungites by measuring fatty acid composition after exposed at different doses for four days in laboratory.

\section{Sample collection}

\section{Materials and Methods}

Fresh corals ( $F$. fungites) were taken from Bidong Island, Terengganu Malaysia. The corals were acclimatized for 2 weeks in well aerated holding polyethylene tanks $(500 \mathrm{~L})$, containing natural seawater with a salinity of $30 \mathrm{ppt}$, under a natural photoperiod 12:12 hours (light: dark) cycle. The water in the tank was passed through a 1-mm filter, treated with UV-sterilized and refilled daily. The coral was not fed at all.

\section{Chemical}

A stock solution of $1000 \mathrm{mg} / \mathrm{L}$ Irgarol was prepared by using acetone and the working concentrations were made up by spiked the required concentrations to the sea water.

\section{Experimental procedures}

F. fungites were acclimatized for two weeks in the laboratory before the acute exposure tests to Irgarol for 96 hours. Water quality characteristics were measured daily: dissolved oxygen (DO) $7.2 \pm 0.5 \mathrm{mg} / \mathrm{L}$, and pH $7.69 \pm 0.2$, but the temperature was automatically controlled to $27{ }^{\circ} \mathrm{C}$ using cooling chiller throughout the whole experiment duration. After the two weeks acclimatization period, corals were transferred into different experimental tanks containing three litres of water and exposed to test concentrations of 20, 100, and $500 \mu \mathrm{g} / \mathrm{L}$ of Irgarol in three replicates for 96 hours. The control and acetone (check-up tanks) were kept for the sake of comparison. After four days ( 96 hours), the tissue of the coral were removed by using water pick and taken to the laboratory for fatty acid analysis.

\section{Analytical procedure}

Tissues of $F$. fungites coral were taken as samples for fatty acid composition analysis. The one step method [17] was used in this experiment to combine extraction and esterification processes using a single tube. Three replicates of each tissue samples $(200-300 \mathrm{mg})$ were mixed with $4 \mathrm{~mL}$ of hexane and $1 \mathrm{~mL}$ of internal standard solution in a $50 \mathrm{~mL}$ centrifuge tube. After adding $2 \mathrm{~mL}$ of $14 \% \mathrm{BF}_{3}$ in methanol and a magnetic stirring bar, the head space of tube was flushed with nitrogen gas and then closed tightly with a Teflon-lined screw-cap. The capped tube was heated on a hot plate at $100{ }^{\circ} \mathrm{C}$ for 120 min under continuous stirring. After cooling to room temperature, $1 \mathrm{~mL}$ of hexane was added followed by $2 \mathrm{~mL}$ of distilled water. The tube was then shaken vigorously for 1 min and centrifuged for $3 \mathrm{~min}$ at $2500 \mathrm{rpm}(650 \times \mathrm{g})$. Of the two phases which formed, the upper phase was hexane layer containing the FAMEs. Finally, approximately $1-2 \mathrm{~mL}$ of the hexane layer was transferred using a Pasteur pipette into a clean sample vial to be injected into the GC-FID for FAME analysis. 
Fatty acid concentrations $\left(C_{F A}, \mathrm{mg} / \mathrm{g}\right.$ of dry sample) were calculated by comparing the peak area of fatty acid in the sample with the peak area of internal standard as equation (1) follows:

$$
C_{F A}=A_{S} /_{A_{I S}} \times{ }^{C_{I S}} / W_{S}
$$

where $A_{S}=$ peak area of fatty acid in the sample in chromatogram, $A_{I S}=$ peak area of internal standard in chromatogram, $C_{I S}=$ concentration of internal standard $(\mathrm{mg})$ and $W_{S}=$ weight of sample $(\mathrm{g}$ ). Qualitatively (as a percentage), composition of individual fatty acids were calculated by comparing the peak area of each fatty acid with the total peak area of all fatty acids in the sample.

\section{Gas chromatography conditions}

The FAMEs were separated and quantified using a gas chromatograph (GC 14-B Shimadzu) equipped with flame ionization detector. Separation was performed with an FFAP-polar capillary column $(30 \mathrm{~m} \times 0.32 \mathrm{~mm}$ internal diameter, $0.25 \mu \mathrm{m}$ film thickness). Purified hydrogen was used as a carrier gas. After injection at $60{ }^{\circ} \mathrm{C}$, the oven temperature was raised to $150{ }^{\circ} \mathrm{C}$ at a rate $40{ }^{\circ} \mathrm{C} \mathrm{min}{ }^{-1}$, then to $230{ }^{\circ} \mathrm{C}$ at $3{ }^{\circ} \mathrm{C} \mathrm{min}{ }^{-1}$, and finally held constant for $30 \mathrm{~min}$. The flame ionization was held at $240{ }^{\circ} \mathrm{C}$. FAME peaks were identified by comparing their retention times with those of authentic standards (Supelco Inc.). Fatty acids were designated as an $n: p \omega x$, where $n$ is the number of carbon atoms in the aliphatic chain, $\mathrm{p}$ is the number of double bonds and $\mathrm{x}$ is the position of the first double bond from the terminal methyl group. The analytical precision for samples was generally $<5 \%$ for total amounts and major components of FAMEs.

\section{Fatty acid composition}

\section{Results and Discussion}

The fatty acid results were calculated and presented as mean \pm standard deviation (Table 1). Significant differences among the mean value of treatments were treated by One-way Analysis of Variance (ANOVA) followed by Least Significant Different (L.S.D). Two-way Analysis of Variance was used to support one way Analysis of Variance to get the F-probability interactions between chemicals, concentrations and / or species. Duncan's multiple range test $(p<0.05)$ were calculated.

Fatty acid composition data for acute exposure of the $F$. fungites in Irgarol are presented in Table 1 . The corals were dominated by SAFA $27.4 \pm 6.17(54.3 \%), 23.8 \pm 5.04(49 \%)$ and $23.2 \pm 6.33(50.6 \%) \mathrm{mg} / \mathrm{g}$ dry weight, followed by PUFA $20.5 \pm 5.48(40.6 \%), 23.2 \pm 6.67(47.8 \%)$ and $20.9 \pm 6.31(45.8 \%) \mathrm{mg} / \mathrm{g}$ dry weight and last is MUFA $2.25 \pm 1.14(5.06 \%), 1.15 \pm 0.69(3.21 \%)$ and $1.65 \pm 0.74(3.61 \%) \mathrm{mg} / \mathrm{g}$ dry weight of fresh, control and acetone samples respectively.

In this study, $F$. fungites samples exposed with 20,100 and $500 \mu \mathrm{g} / \mathrm{L}$ Irgarol have the same trend as fresh, control and acetone samples of SAFA > PUFA > MUFA (Figure 1). It was noted that SAFA, PUFA and MUFA are reduced as the dose of Irgarol increased in tested species. It is also interesting to note that in F. fungites (Figure 1), MUFA groups contributed less in the total FA among all exposed groups. The behavior of some groups of corals organisms to show different trends as in fresh and control samples can be justified by the fact that the activities in these groups were affected not only by the chemicals but also the ability of the individual organism to fight the toxic behavior of the used chemical.

\section{Saturated fatty acids (SAFA)}

The $F$. fungites are relatively enriched in Saturated Fatty Acids (SAFA) and the total SAFA are not significant different $(p>0.05)$ between fresh and control groups, however the other groups and individual SAFA were significant difference $(p<0.05)$ in this species (Table 1). Palmitic acid (C16:0) was found dominant in all SAFAs of the $F$. fungites (Table 1$)$ and showed a significant difference $(p<0.05)$ between the samples. SAFA is pronounced more in average in $F$. Fungites (Figure 1). It was also reported that palmitic acid was the predominant in SAFA group as found in freshwater channel catfish (Ictalurus punctatus) (19.2 \%) [18], and in freshwater rainbow trout (Oncorhynchus mykiss) (21.3\%) [19]. The fresh water species domination on SAFA fatty acids is also reported in the study conducted by Jabeen and Chaundhry [20]. 
Zainudin et al: EFFECTS OF IRGAROL-1051 ON FATTY ACID PROFILE OF SOLITARY CORALS, Fungia fungites AFTER ACUTE EXPOSURE

Table 1. Fatty acid composition (mg/g) dry weight of tissue samples of Fungia fungites (mushroom) after 96 hours acute exposure test. Values are means \pm standard deviation (SD) for $n=3$.

\begin{tabular}{|c|c|c|c|c|c|c|}
\hline \multirow{2}{*}{ Fatty Acids } & \multirow{2}{*}{ Fresh } & \multirow{2}{*}{ Control } & \multirow{2}{*}{ Acetone } & \multicolumn{3}{|c|}{ Irgarol } \\
\hline & & & & $20 \mu \mathrm{g} / \mathrm{L}$ & $100 \mu \mathrm{g} / \mathrm{L}$ & $500 \mu \mathrm{g} / \mathrm{L}$ \\
\hline \multicolumn{7}{|l|}{ SAFA } \\
\hline $\mathrm{C} 14: 0$ & $2.05^{\mathrm{a}} \pm 0.58$ & $1.57^{\mathrm{b}} \pm 0.08$ & $1.40^{\mathrm{b}} \pm 0.16$ & $1.41^{\mathrm{b}} \pm 0.08$ & $1.58^{\mathrm{b}} \pm 0.13$ & $1.60^{\mathrm{b}} \pm 0.13$ \\
\hline C16:0 & $15.9^{\mathrm{a}} \pm 1.39$ & $13.2^{b c} \pm 1.53$ & $15.2^{\mathrm{ab}} \pm 1.77$ & $14.1^{\mathrm{ab}} \pm 1.64$ & $11.4^{\mathrm{c}} \pm 1.20$ & $6.25^{\mathrm{d}} \pm 0.61$ \\
\hline C18:0 & $5.27^{\mathrm{a}} \pm 0.34$ & $5.15^{\mathrm{a}} \pm 0.18$ & $3.84^{\mathrm{ab}} \pm 0.44$ & $4.39^{\mathrm{a}} \pm 1.01$ & $3.69^{\mathrm{ab}} \pm 0.47$ & $4.46^{\mathrm{a}} \pm 0.97$ \\
\hline C20:0 & $4.21^{\mathrm{a}} \pm 0.15$ & $3.89^{\mathrm{ab}} \pm 0.61$ & $2.76^{\mathrm{c}} \pm 0.11$ & ND & $3.44^{\mathrm{bc}} \pm 0.31$ & ND \\
\hline \multicolumn{7}{|l|}{ MUFA } \\
\hline $\mathrm{C} 16: 1$ & $2.55^{\mathrm{a}} \pm 0.45$ & $1.55^{\mathrm{c}} \pm 0.18$ & $1.65^{\mathrm{bc}} \pm 0.08$ & $1.78^{\mathrm{bc}} \pm 0.13$ & $1.41^{\mathrm{c}} \pm 0.61$ & $1.56^{\mathrm{bc}} \pm 0.07$ \\
\hline $\mathrm{C} 17: 1$ & ND & ND & ND & ND & ND & ND \\
\hline $\mathrm{C} 18: 1 \omega 9$ & ND & ND & ND & ND & ND & ND \\
\hline C20:1 & ND & ND & ND & ND & ND & ND \\
\hline \multicolumn{7}{|l|}{ PUFA } \\
\hline $\mathrm{C} 18: 3 \omega 6$ & $3.03^{b c} \pm 0.12$ & $3.30^{\mathrm{b}} \pm 0.22$ & $2.28^{c} \pm 0.19$ & $2.29^{c} \pm 0.29$ & $6.15^{\mathrm{a}} \pm 0.25$ & $2.84^{\mathrm{bc}} \pm 1.05$ \\
\hline $\mathrm{C} 18: 3 \omega 3$ & $13.7^{\mathrm{bc}} \pm 1.07$ & $16.4^{\mathrm{a}} \pm 0.76$ & $15.1^{\mathrm{ab}} \pm 0.86$ & $11.7^{\mathrm{d}} \pm 1.04$ & 0.00 & 0.00 \\
\hline $\mathrm{C} 20: 3 \omega 3$ & $1.24^{\mathrm{cd}} \pm 0.30$ & $2.04^{\mathrm{a}} \pm 0.14$ & $1.06^{\mathrm{d}} \pm 0.07$ & $1.45^{\mathrm{bcd}} \pm 0.19$ & $1.01^{\mathrm{d}} \pm 0.11$ & $2.29^{\mathrm{a}} \pm 0.26$ \\
\hline $\mathrm{C} 20: 5 \omega 3$ & $2.54^{\mathrm{a}} \pm 0.08$ & $1.46^{\mathrm{b}} \pm 0.25$ & $2.55^{\mathrm{a}} \pm 0.23$ & ND & ND & ND \\
\hline $\mathrm{C} 22: 6 \omega 3$ & ND & ND & ND & ND & ND & ND \\
\hline$\overline{\Sigma S A F A}$ & $27.4^{\mathrm{a}} \pm 6.17$ & $23.8^{\mathrm{ab}} \pm 5.04$ & $23.2^{\mathrm{ab}} \pm 6.33$ & $19.9^{\mathrm{b}} \pm 6.39$ & $20.1^{\mathrm{b}} \pm 4.37$ & $12.3^{\mathrm{cd}} \pm 2.85$ \\
\hline$\Sigma$ MUFA & $2.55^{\mathrm{a}} \pm 1.14$ & $1.55^{\mathrm{c}} \pm 0.69$ & $1.65^{\mathrm{bc}} \pm 0.74$ & $1.78^{\mathrm{bc}} \pm 0.80$ & $1.41^{\mathrm{c}} \pm 0.80$ & $1.56^{\mathrm{bc}} \pm 0.70$ \\
\hline$\Sigma$ PUFA & $20.5^{\mathrm{ab}} \pm 5.48$ & $23.2^{\mathrm{a}} \pm 6.67$ & $20.9^{\mathrm{ab}} \pm 6.31$ & $15.4^{\mathrm{c}} \pm 4.92$ & $7.2^{\mathrm{d}} \pm 2.67$ & $5.1^{\mathrm{d}} \pm 1.43$ \\
\hline$\Sigma \mathrm{FA}$ & $50.4^{\mathrm{a}} \pm 5.04$ & $48.5^{\mathrm{a}} \pm 5.18$ & $45.8^{\mathrm{ab}} \pm 5.18$ & $37.1^{\mathrm{b}} \pm 4.58$ & $28.7^{\mathrm{c}} \pm 3.30$ & $19.0^{\mathrm{d}} \pm 2.02$ \\
\hline
\end{tabular}

SAFA: Saturated fatty acids; MUFA: Monounsaturated fatty acids; PUFA: Polyunsaturated fatty acids; Means within rows followed by the same superscript(s) are not significant different $(p>0.05)$; ND - Not detected

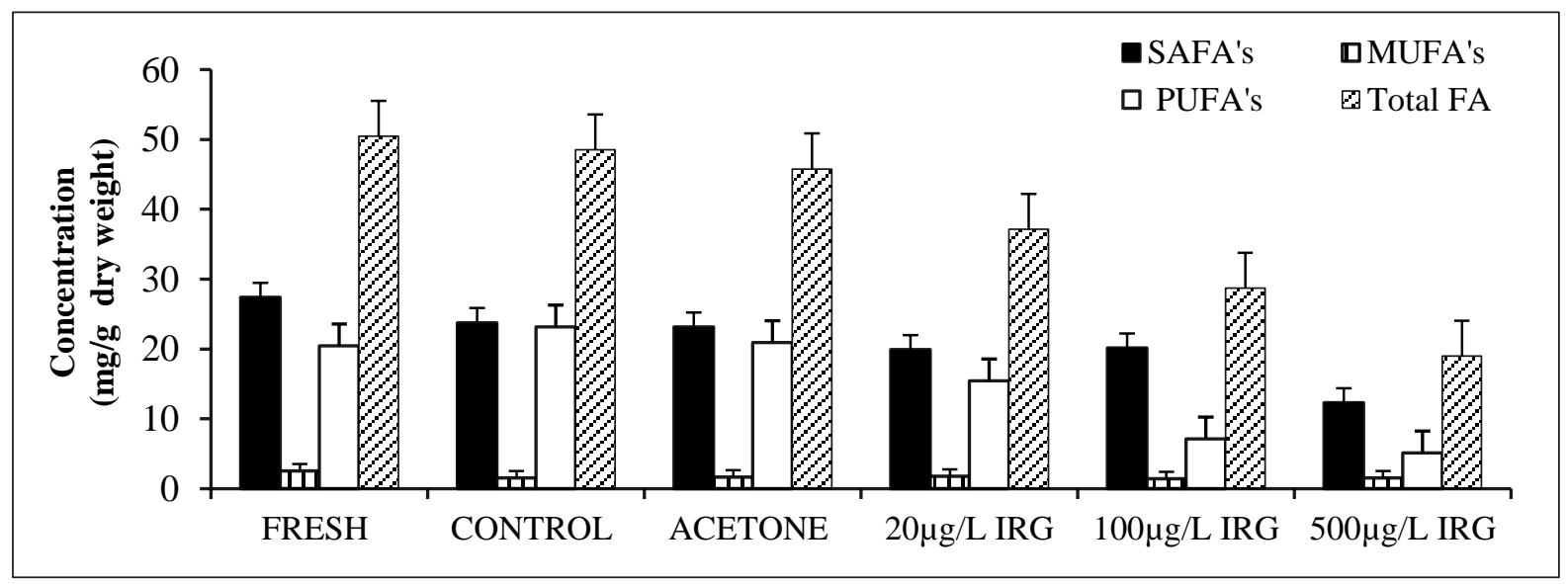

Figure 1. Fatty acid concentration of different classes and total fatty acid (mg/g dry weight) from tissues of Fungia fungites after exposed at different concentrations of Irgarol. Values are mean \pm S.D, $n=3$. 


\section{Mono unsaturated fatty acids (MUFA)}

The $\Sigma$ MUFA for $F$. fungites were significant difference in fresh, control, acetone and other exposed concentrations (Table 1). It is observed that MUFA contribution is less in total fatty acids in F. fungites (Table 1). This is due to the fact that, only palmitoleic acid (C16:1) was observed in the GC-FID where the rest of MUFA were below the detectable limit. In fact, Ho and Paul [21] found about $8 \%$ only of oleic acid in total fatty acid in Asian sea bass. However, Steiner-Asiedu et al. [22] found that freshwater tilapia (Tilapia sp.) had significantly higher oleic acid levels than flat sardine (Sardinella) and sea bream (Dentex). The level of oleic acid in American freshwater channel catfish flesh was also reported higher; about $50 \%$ [23] compared to less than 1\% in sardine and sea mullet [24].

\section{Polyunsaturated fatty acids (}

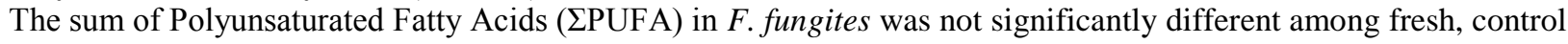
and acetone samples $(p>0.05)$. $\alpha$-Linolenic acid $(\mathrm{C} 18: 3 \omega 3)$ was dominant PUFA in $F$. fungites $(66.8 \%$ fresh sample) (see Figures $1 \& 2$ ). The rest of the PUFA in this species have less contribution. The higher levels of omega 3 and 6 in this species was not surprising because seawater organisms obtain their omega-3 and 6 FA from oceanic plankton $[16,25]$ or are fed fishmeal containing these FA [26].

Individual fatty acids were not detected in some exposed groups which differed with fresh and control groups (Figure 2). For example, $\alpha$-Linolenic acid (C18:3 133$)$ was not detected in $F$. fungites exposed in this biocide at 100 and $500 \mu \mathrm{g} / \mathrm{L}$ whereas $\mathrm{C} 20: 5 \omega 3$ was not detected in all exposed groups (Figure 2). As expected, individual fatty acids in $500 \mu \mathrm{g} / \mathrm{L}$ exposure groups were much affected than the rest of the groups in F. fungites (Figure 2). The results show an inverse relationship between the dose of chemical used and activities of the $F$. fungites in the tanks. It is clear that, as the concentration of the Irgarol increased in different exposed tanks there was a decrease in activities of $F$. fungites.

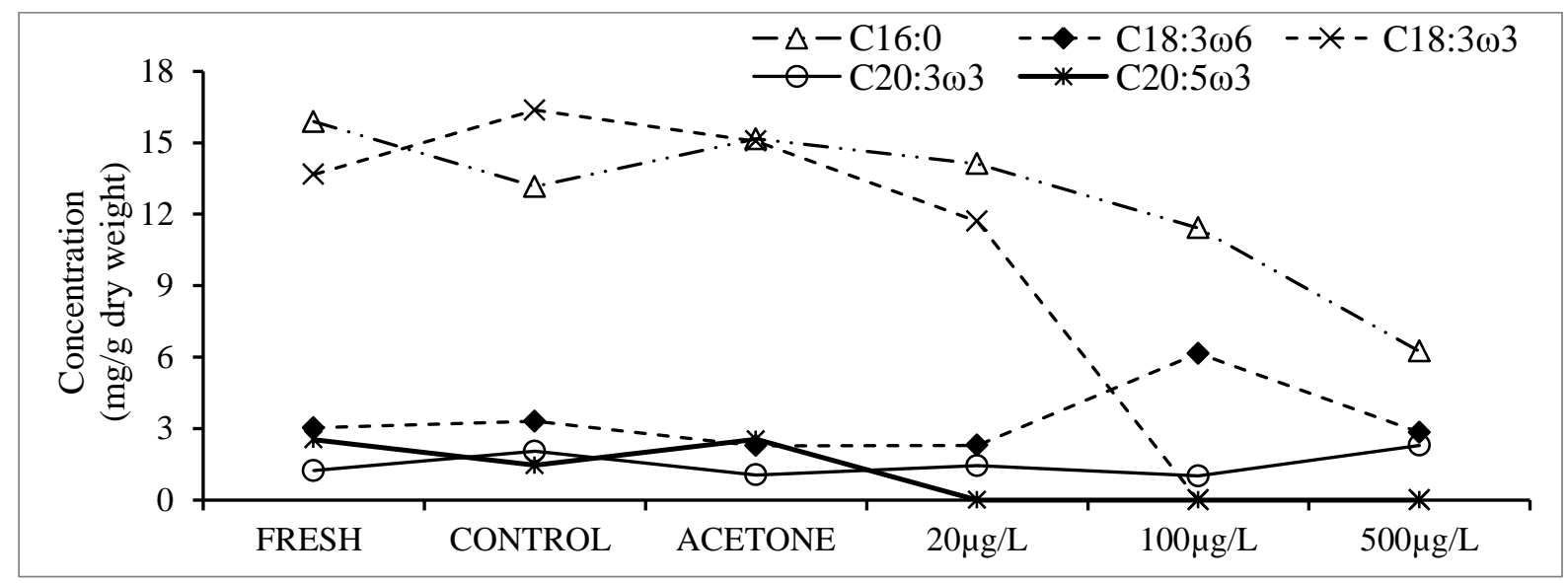

Figure 2. Individual Fatty acid concentrations of Fungia fungites exposed at different doses of Irgarol.

\section{Conclusion}

This paper explains the toxicological responses of $F$. fungites upon exposure to different concentrations of Irgarol in laboratory experiments. It can be concluded that; acute exposure of $F$. fungites (96 hours) to different concentrations of Irgarol had shown significant impact to the fatty acid composition. Fresh, control and all exposed samples of $F$. fungites were in trend of SAFA > PUFA > MUFA, however the exposed samples suffer more as the dose of Irgarol increased. The results of this study reveal that Irgarol is toxic and reduce the fatty acid composition of the coral even at the low level of exposure $(20 \mu \mathrm{g} / \mathrm{L})$ and for a short period of time (96 hours). There is a need of further researches to be conducted in this area of specialization so as to understand more effects of these new antifouling chemicals to marine organisms as well as in coral reef using different species. 


\section{Acknowledgement}

We sincerely acknowledge the Ministry of Education of Malaysia (MOE) for providing fund to support conducting this study using Fundamental Research Grant Scheme (FRGS/1/2011/STWN/UMT/02/3) and Higher Centre of Excellent (HiCOE) program. We also acknowledge University of Malaysia Terengganu (UMT) special Institute of Oceanography and Environment (INOS), School of Marine and Environmental Sciences, and the State University of Zanzibar (SUZA) for their support in conducting this research.

\section{References}

1. Gatidou, G., Thomaidis, N. S. and Zhou, J. L. (2007). Fate of Irgarol 1051, diuron and their main metabolites in two UK marine systems after restrictions in antifouling paints. Environment International, 33(1): 70 - 77.

2. Ali, H. R., Arifin, M. M., Sheikh, M. A., Mohamed Shazili, N. A. and Bachok, Z. (2013). Occurrence and distribution of antifouling biocide Irgarol-1051 in coastal waters of Peninsular Malaysia. Marine Pollution Bulletin, 70(1-2): 253 - 257

3. Gardinali, P. R., Plasencia, M., Mack, S. and Poppell, C. (2002). Occurrence of Irgarol 1051 in coastal waters from Biscayane Bay, Florida, USA. Marine Pollution Bulletin, 44: 781 - 788.

4. Knutson, S., Downs, C. A. and Richmond, R. H. (2012). Concentrations of Irgarol in selected marinas of Oahu, Hawaii and effects on settlement of coral larval. Ecotoxicology, 21(1): $1-8$.

5. Jones, R. J. and Heyward, A. J. (2003). The effects of produced formation water (PFW) on coral and isolated symbiotic dinoflagellates of coral. Marine and Freshwater Research, 54(2): 153 - 162.

6. Tolosa, I., Readman, J. W., Blaevoet, A., Ghilini, S., Bartocci, J. and Horvat, M. (1996). Contamination of Mediterranean (Cite d'Azur) coastal waters by organotins and Irgarol 1051 used in antifouling paints. Marine Pollution Bulletin, 32(4): 335 - 341.

7. Owen, R., Knap, A., Toaspern, M. and Carbery, K. (2002). Inhibition of coral photosynthesis by the antifouling herbicide Irgarol 1051. Marine Pollution Bulletin, 44(7): 623 - 632.

8. Okamura, H., Aoyama, I., Ono, Y. and Nishida, T. (2003). Antifouling herbicides in the coastal waters of western Japan. Marine Pollution Bulletin, 47: 59 - 67.

9. Sapozhnikova, Y., Wirth, E., Schiff, K., Brown, J. and Fulton, M. (2007). Antifouling pesticides in the coastal waters of Southern California. Marine Pollution Bulletin, 54(12): 1972 - 1978.

10. Sheikh, M. A., Higuchi, T., Fujimura, H., Imo, T. S., Miyagi, T. and Oomori, T. (2009). Contamination and impacts of new antifouling biocide Irgarol-1051 on subtropical coral reef waters. International Journal of Environmental Science and Technology, 6(3): 353 - 358.

11. Biselli, S., Bester, K., Hühnerfuss, H. and Fent, K. (2000). Concentrations of the antifouling compound Irgarol 1051 and of organotins in water and sediments of German North and Baltic Sea marinas. Marine Pollution Bulletin, 40(3): $233-243$.

12. Boxall, A. B. A., Comber, S. D., Conrad, A. U., Howcroft, J. and Zaman, N. (2000). Inputs, monitoring and fate modelling of antifouling biocides in UK estuaries. Marine Pollution Bulletin, 40(11): 898 - 905.

13. Kitada, Y., Kawahata, H., Suzuki, A. and Oomori, T. (2008). Distribution of pesticides and bisphenol a in sediments collected from rivers adjacent to coral reefs. Applied Catalysis B: Environmental, 82(3-4): 163 -168.

14. Thomas, K. V., McHugh, M. and Waldock, M. (2002). Antifouling paint booster biocides in UK coastal waters: Inputs, occurrence and environmental fate. Science of the Total Environment, 293(1-3): 117 - 127.

15. Basheer, C., Tan, K. S. and Lee, H. K. (2002). Organotin and Irgarol-1051 contamination in Singapore coastal waters. Marine Pollution Bulletin, 44(7): 697 - 703.

16. Ali, H. R., Arifin, M. M., Sheikh, M. A., Mohamed Shazili, N. A. and Bachok, Z. (2015). Toxicological studies of Irgarol-1051 and its effects on fatty acid composition of Asian sea-bass, Lates calcarifer. Regional Studies in Marine Science, 2: $171-176$.

17. Abdulkadir, S. and Tsuchiya, M. (2008). One-step method for quantitative and qualitative analysis of fatty acids in marine animal samples. Journal of Experimental Marine Biology and Ecology, 354(1): 1-8.

18. Sathivel, S., Prinyawiwatkul, W., Grimm, C. C., King, J. M. and Lloyd, S. (2002). FA composition of crude oil recovered from catfish viscera. Journal of the American Oil Chemists' Society, 79(10): 989 - 992.

19. İbrahim Haliloğlu, H., Bayır, A., Necdet Sirkecioğlu, A., Mevlüt Aras, N. and Atamanalp, M. (2004). Comparison of fatty acid composition in some tissues of rainbow trout (Oncorhynchus mykiss) living in seawater and freshwater. Food Chemistry, 86(1): $55-59$. 
20. Jabeen, F. and Chaudhry, A. S. (2011). Chemical compositions and fatty acid profiles of three freshwater fish species. Food Chemistry, 125(3): $991-996$.

21. Ho, B. T. and Paul, D. R. (2009). Fatty acid profile of Tra Catfish (Pangasius hypophthalmus) compared to Atlantic Salmon (Salmo solar) and Asian Seabass (Lates calcarifer). International Food Research Journal, 16(4): $501-506$.

22. Steiner-Asiedu, M., Julshamn, K. and Lie, Ø. (1991). Effect of local processing methods (cooking, frying and smoking) on three fish species from Ghana: Part I. Proximate composition, fatty acids, minerals, trace elements and vitamins. Food Chemistry, 40(3): $309-321$.

23. Nettleton, J. A., Allen, W. H., Klatt, L. V., Ratnayake, W. M. N. and Ackman, R. G. (1990). Nutrients and chemical residues in one-to two-pound Mississippi farm-raised channel catfish (Ictalurus punctatus).Journal of Food Science, 55(4): 954 - 958.

24. Ackman, R. G. (1994). Seafood lipids. In Shahidi, F. and Botta, J. R. (Eds). Seafoods: Chemistry, Processing, Technology and Quality. Glasgow: Chapman and Hall p. $34-48$.

25. Steffens, W. (1997). Effects of variation in essential fatty acids in fish feeds on nutritive value of freshwater fish for humans. Aquaculture, 151: 97 - 119.

26. Henderson, R. J. (1996). Fatty acid metabolism in freshwater fish with particular reference to polyunsaturated fatty acids. Archives of Animal Nutrition, 49(1): 5-22. 